\title{
Adrenal Cortical Function in Children on Steroids
}

\author{
JAN A. KUZEMKO and JOHN G. LINES \\ From the Paediatric Department, Peterborough District Hospital, Peterborough; and Biochemical Section, John Bonnett \\ Clinical Laboratories, Addenbrooke's Hospital, Cambridge
}

\begin{abstract}
Kuzemko, J. A., and Lines, J. G. (1970). Archives of Disease in Childhood, 45, 215. Adrenal cortical function in children on steroids. Adrenal cortical function was assessed in 20 children receiving 2.5 to $10 \mathrm{mg}$. prednisolone daily, by measuring plasma cortisol levels before and after the administration of the synthetic polypeptide $\beta^{1-24}$, tetracosactrin (Synacthen). 18 of the children were asthmatics, one had nephrosis, and one had dermatomyositis.

Adrenal function was classified as (a) abnormal response to tetracosactrin, where basal plasma cortisol and post-tetracosactrin levels did not exceed $6 \mu \mathrm{g} . / 100 \mathrm{ml}$; (b) partial response, where there was a rise of 5-10 $\mu \mathrm{g} . / 100 \mathrm{ml}$. in plasma cortisol following tetracosactrin but the basal levels $(<10 \mu \mathrm{g} . / 100 \mathrm{ml}$.) were below or only slightly above the lower normal limit; (c) normal response, where there was usually at least a doubling of the basal value and an incremental increase of at least $10 \mu \mathrm{g} . / 100 \mathrm{ml}$. in the plasma cortisol concentrations following tetracosactrin.

All 6 children receiving the higher dosage of $10 \mathrm{mg}$. prednisolone daily had abnormal adrenal function. 4 receiving the lower dosage of $2.5 \mathrm{mg}$./day had satisfactory adrenal reserve. Of the 10 children receiving the intermediate dosage of $5 \mathrm{mg}$. prednisolone daily, 2 had frankly abnormal adrenocortical function, 3 had poor adrenal reserve, and 5 produced good incremental values, though their baseline cortisol levels were low. At the $5 \mathrm{mg}$. prednisolone dose adrenocortical suppression was not correlated either with duration of therapy or with age.
\end{abstract}

It is well known that exogenous corticosteroids depress adrenal cortical function (Shuster and Williams, 1961; Treadwell et al., 1963), and there is some evidence that adrenocortical suppression occurs in asthmatic children receiving low doses of corticosteroids (Kerrebijn, de Kroon, and Harders, 1967). The present investigation was undertaken to determine to what extent children on long-term corticosteroid therapy were subject to suppression of adrenal cortical function, and if possible to relate this to the amounts of steroid administered, as Wood et al. (1965) have done for the adult.

Adrenal cortical function was assessed from plasma cortisol levels before and after the administration of tetracosactrin. The '30-minute tetracosactrin test' has the particular advantage for work on children that it is rapidly completed, is free from allergic effects that can occur with the natural corticotrophins (Wilson, 1951; Pearson, 1959), and is preferable to the pyrogen stress (Melby, 1959) or insulin (Landon,

Received 8 September 1969.
Wynn, and James, 1963) tests of adrenal reserve. Its validity as a reliable assessment of adrenocortical reserve in adults is well established (Wood et al., 1965; Greig et al., 1966), but reports of its use in children are few (Alleyne and Young, 1966; Rao, Srikantia, and Gopalan, 1968). In the adult an approximate doubling of the plasma cortisol concentration, following $250 \mu \mathrm{g}$. tetracosactrin intramuscularly, above an $8 \mathrm{a} . \mathrm{m}$. value of $6-26 \mu \mathrm{g} . / 100 \mathrm{ml}$. is indicative of normal adrenal function. It is possible, however, that these criteria may require some modification for the assessment of adrenocortical function in children, or in those patients in whom a more precise knowledge of the extent of adrenal cortical malfunction is required.

\section{Subjects and Methods}

Eighteen children with asthma and two other children, with dermatomyositis and nephrosis, respectively, were studied. All had been on prednisolone for at least 4 months, the dose varying between 2.5 and $10 \mathrm{mg}$. daily. Severity of the asthma was assessed in 13 children by the criteria described by Jones (1966); the 
remaining 5 asthmatic children were too young to cooperate in the respiratory studies. Tuberculin test, blood count, and $x$-rays of lungs and sinuses were routinely carried out.

The tetracosactrin tests were done on children as out-patients. After half an hour's rest, a sample of blood was collected for the baseline cortisol assay and then $250 \mu \mathrm{g}$. tetracosactrin in $2 \mathrm{ml}$. saline was given intramuscularly. A second sample of blood was collected 30 minutes after the injection. No complications were encountered, though some children complained of a stinging feeling after the intramuscular injection. In 5 children repeated tetracosactrin tests were performed, and in 4 the tests were repeated after the administration of tetracosactrin ( $1 \mathrm{mg}$. i.m.) on 3 consecutive days. Blood was collected into heparinized plastic syringes, and the plasma was rapidly separated from the cells and deep-frozen until analysis. Plasma cortisol concentrations were measured by the Mattingly (1962) modifications of the de Moor et al. (1960) procedure, using the Aminco-Bowman spectrofluorimeter for the fluorescence measurements.

\section{Results}

The results of the plasma cortisol analyses before and after tetracosactrin, together with clinical details, are shown in Tables I, II, or III, according to whether the daily prednisolone dose was $2 \cdot 5,5$, or $10 \mathrm{mg}$. To classify response to tetracosactrin, it was found necessary to have three categories: frankly abnormal (A), that is where the baseline values were subnormal and 30 minutes after tetracosactrin the plasma cortisol concentration did not exceed $6 \mu \mathrm{g} . / 100 \mathrm{ml}$; partial response (PR) in which, though the baseline values were either near the lower limit of normal, i.e. not in excess of $10 \mu \mathrm{g} . / 100 \mathrm{ml}$., or subnormal, there was a rise of $5-10 \mu \mathrm{g} . / 100 \mathrm{ml}$. in the plasma cortisol level after tetracosactrin; and normal $(\mathrm{N})$ in which there was usually at least a doubling of the baseline values $\frac{\text { ? }}{\overline{\frac{3}{2}}}$ after tetracosactrin and an incremental increase of ? at least $10 \mu \mathrm{g} . / 100 \mathrm{ml}$. This latter category could $\overrightarrow{\bar{F}}$ be further subdivided into those patients who had of normal baseline value $(\mathrm{N})$, a subnormal baseline value $\left(\mathrm{N}^{\star}\right)$, or a baseline value in the upper thirde of the normal range $\left(N^{\star \star}\right)$. The significance of classifying the results in this way will be discussed later.

It can be seen that there is a direct correlation $\overrightarrow{0}$ between the dosage of prednisolone and adrenaicortical activity. All 4 children receiving $2.5 \mathrm{mg} \omega$ prednisolone daily had adequate adrenocorticahy reserve. The 6 who were receiving $10 \mathrm{mg}$./dayo gave abnormal results, and these were confirmed in 3 children by repeated testing. Of the 10 childreriv receiving $5 \mathrm{mg}$. prednisolone daily (including thes two with nephrosis and dermatomyositis), 2 hadi frankly abnormal adrenocortical function, 3 had poor adrenal reserve (a partial response to tetracosactrin), and while the remaining 5 produced good incremental values, their baseline cortisol levelo were low. Reduction in the steroid dose from 10 . to $2.5 \mathrm{mg}$. daily in 2 of the children (Cases 3 and $4 . \overrightarrow{0}$ Table III) resulted in satisfactory responses $D$ though baseline values were still low when tested after two months on the lower dose. A reduction from 10 to $5 \mathrm{mg}$. prednisolone daily in 2 othero children (Cases 1 and 2, Table III) also resulte in improved adrenal cortical function, though in one of them (Case 2) there was a deterioration after a further month on the lower dose.

Of the 18 asthmatic children, none required more than $10 \mathrm{mg}$. prednisolone daily to control their asthma: 8 belonged to Group III (severe asthma) and 5 to Group II (moderate asthma), according t\& the Jones classification (Jones, 1966). As migh $\frac{\bar{P}}{O}$

TABLE I

Children on 2.5 mg. Prednisolone Daily

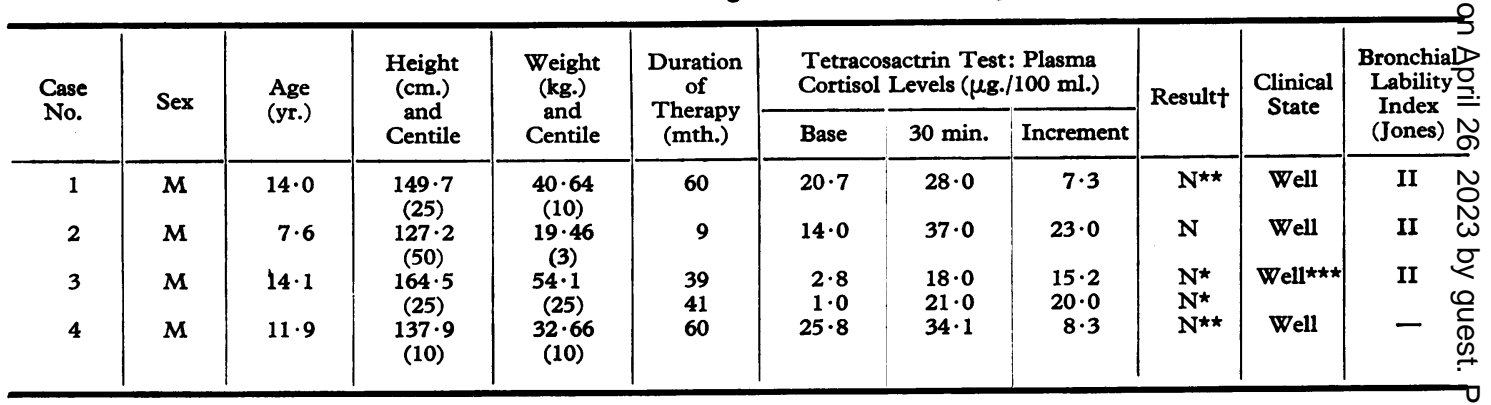

†Normal, N (see text). †Normal, $N$ (see text).
$\star \star \star$ Four months previously admitted in severe status asthmaticus; required bronchial washout and assisted ventilation; received then 4-daß
course of tetracosactrin depot $1 \mathrm{mg}$. daily.

Height and weight centiles are derived from the Tables of Tanner et al. (1966). 
TABLE II

Children on 5 mg. Prednisolone Daily

\begin{tabular}{|c|c|c|c|c|c|c|c|c|c|c|c|}
\hline \multirow{2}{*}{$\begin{array}{l}\text { Case } \\
\text { No. }\end{array}$} & \multirow{2}{*}{ Sex } & \multirow{2}{*}{$\begin{array}{l}\text { Age } \\
\text { (yr.) }\end{array}$} & \multirow{2}{*}{$\begin{array}{l}\text { Height } \\
\text { (cm.) } \\
\text { and } \\
\text { Centile }\end{array}$} & \multirow{2}{*}{$\begin{array}{l}\text { Weight } \\
\text { (kg.) } \\
\text { and } \\
\text { Centile }\end{array}$} & \multirow{2}{*}{$\begin{array}{l}\text { Duration } \\
\text { of } \\
\text { Therapy } \\
\text { (mth.) }\end{array}$} & \multicolumn{3}{|c|}{$\begin{array}{l}\text { Tetracosactrin Test: Plasma } \\
\text { Cortisol Levels }(\mu \mathrm{g} . / 100 \mathrm{ml} .)\end{array}$} & \multirow{2}{*}{ Result $†$} & \multirow{2}{*}{$\begin{array}{l}\text { Clinical } \\
\text { State }\end{array}$} & \multirow{2}{*}{$\begin{array}{l}\text { Bronchial } \\
\text { Lability } \\
\text { Index } \\
\text { (Jones) }\end{array}$} \\
\hline & & & & & & Base & $30 \mathrm{~min}$. & Increment & & & \\
\hline 1 & $\mathbf{M}$ & $9 \cdot 1$ & $\begin{array}{c}128 \cdot 7 \\
(10)\end{array}$ & $\begin{array}{l}25 \cdot 76 \\
(25)\end{array}$ & $\begin{array}{l}21 \\
23\end{array}$ & $\begin{array}{l}1 \cdot 2 \\
1 \cdot 3\end{array}$ & $\begin{array}{l}9 \cdot 2 \\
7 \cdot 2\end{array}$ & $\begin{array}{l}8 \cdot 0 \\
5 \cdot 9\end{array}$ & $\begin{array}{l}\text { PR } \\
\text { PR }\end{array}$ & Well & III \\
\hline 2 & $M$ & $9 \cdot 4$ & $\begin{array}{l}134 \cdot 0 \\
(50)\end{array}$ & $\begin{array}{r}23 \cdot 3 \\
(3)\end{array}$ & 13 & $4 \cdot 4$ & $17 \cdot 9$ & $13 \cdot 5$ & $\mathrm{~N}^{\star}$ & Well & III \\
\hline 3 & $\mathbf{M}$ & $7 \cdot 3$ & $\begin{array}{c}114 \cdot 4 \\
(3)\end{array}$ & $\begin{array}{l}18 \cdot 58 \\
\text { (3) }\end{array}$ & 14 & $6 \cdot 7$ & $13 \cdot 9$ & $7 \cdot 2$ & PR & $\begin{array}{r}\text { Needs occasional } \\
\text { bronchodilator }\end{array}$ & III \\
\hline 4 & $\mathbf{M}$ & $5 \cdot 1$ & $\begin{array}{l}114 \cdot 6 \\
(75)\end{array}$ & $\begin{array}{c}16 \cdot 50 \\
(10)\end{array}$ & 5 & $1 \cdot 7$ & $16 \cdot 6$ & $14 \cdot 9$ & $N^{\star}$ & $\begin{array}{l}\text { Attends psychiatrist; } \\
\text { needs bronchodilators }\end{array}$ & $\begin{array}{r}\text { Too young } \\
\text { to assess }\end{array}$ \\
\hline 5 & $\mathrm{~F}$ & $6 \cdot 2$ & $\begin{array}{c}117 \cdot 5 \\
(50)\end{array}$ & $\begin{array}{c}20 \cdot 68 \\
(25)\end{array}$ & 5 & $6 \cdot 8$ & $16 \cdot 8$ & $10 \cdot 0$ & $\mathrm{~N}$ & Well & $\begin{array}{c}\text { Too young } \\
\text { to assess }\end{array}$ \\
\hline 6 & $M$ & $10 \cdot 2$ & $\begin{array}{c}137 \cdot 5 \\
(25)\end{array}$ & $\begin{array}{c}36 \cdot 11 \\
(75)\end{array}$ & 5 & $9 \cdot 2$ & $13 \cdot 7$ & $4 \cdot 5$ & PR & Well & II \\
\hline 7 & $M$ & $6 \cdot 2$ & $\begin{array}{c}116 \cdot 5 \\
(50)\end{array}$ & $\begin{array}{c}22 \cdot 50 \\
(50)\end{array}$ & 52 & $7 \cdot 1$ & $27 \cdot 8$ & $20 \cdot 1$ & $\mathbf{N}$ & Well & $\begin{array}{l}\text { Too young } \\
\text { to assess }\end{array}$ \\
\hline 8 & $\mathbf{M}$ & $11 \cdot 0$ & $\begin{array}{l}140 \cdot 0 \\
(25)\end{array}$ & $\begin{array}{c}30 \cdot 10 \\
(10)\end{array}$ & 4 & $3 \cdot 1$ & $5 \cdot 0$ & $1 \cdot 9$ & A & $\begin{array}{l}\text { Well on steroid }+ \\
\text { disodium cromoglycate; } \\
\text { relapses if steroids } \\
\text { reduced } \star \star \star\end{array}$ & III \\
\hline 9 & $\mathbf{M}$ & $11 \cdot 1$ & $\begin{array}{l}142 \cdot 1 \\
(25)\end{array}$ & $\begin{array}{l}25 \cdot 17 \\
(3)\end{array}$ & 9 & $1 \cdot 5$ & $4 \cdot 1$ & $2 \cdot 6$ & $\mathbf{A}$ & $\begin{array}{l}\text { Well on steroid and } \\
\text { disodium cromoglycate }\end{array}$ & II \\
\hline 10 & $\mathbf{M}$ & 10.9 & $\begin{array}{l}115 \cdot 0 \\
(<3)\end{array}$ & $\begin{array}{l}19 \cdot 14 \\
(<3)\end{array}$ & 48 & $1 \cdot 9$ & $22 \cdot 1$ & $20 \cdot 2$ & $N^{\star}$ & - & - \\
\hline
\end{tabular}

†For classification of results, normal (N), partial (PR) or abnormal (A), see text.

$\star \star \star$ Hodgkin's disease, cervical glands. No residual glands after radiotherapy.

Height and weight centiles are derived from the Tables of Tanner et al. (1966).

be expected in this highly selected group of asthmatic children, i.e. the more severely affected, the heights of only 2 were on the third centile (Case 5, Table III, and Case 3, Table II), 2 were on the 10th centile, 6 on the 25 th, 7 on the 50th, and 1 on the 75th centile (Tanner, Whitehouse, and Takaishi, 1966). All children in Group III required measures besides steroid therapy for the control of their symptoms, e.g. occasional bronchodilators, disodium cromoglycate, or psychiatric advice. In addition, 4 of the children in the group receiving the highest dose of prednisolone were given a short course of tetracosactrin depot after reduction of the prednisolone dosage, as indicated in Table III, but in no case would the effects be maintained at the times of subsequent acute tetracosactrin tests.

\section{Discussion}

In addition to the specific results of this study, there are three points which need comment: the interpretation of the stimulation tests in children; the possible clinical signs of adrenal cortical suppression; and more broadly, the causes of death in children with asthma.

Interpretation of tetracosactrin stimulation tests for the evaluation of adrenocortical inhibition as 'normal' or 'abnormal', by the criteria of Wood et al. (1965), may be adequate for some purposes, but we have judged it preferable to classify results as showing, (a) no response, (b) partial response, or (c) normal response. A partial response implies that the adrenal cortex is able to produce some corticosteroids following the stimulus of a corticotrophin, but the increment in plasma cortisol is less than $10 \mu \mathrm{g} . / 100 \mathrm{ml}$. These patients would probably be able to respond adequately to the stress of infection, operation, or other trauma, though supplementary steroid/ACTH cover would be a wise precaution.

Plasma cortisol concentrations in normal adults show a very wide range of values even when measured at a standard time of day (usually 8 or 10 a.m.), varying from about 6 to $25 \mu \mathrm{g} . / 100 \mathrm{ml}$. (Wood et al., 1965; Greig et al., 1966; and confirmed in our own laboratory). In addition, plasma cortisol concentrations are subject to circadian rhythms of varying magnitude from person to person which give variable incremental values to tetracosactrin stimulation, depending on the time of day when the test was performed (Mills, 1966; McGill et al., 1967). There is, therefore, a wide range of plasma cortisol levels reported as representing normal adrenocortical activity, both before and as an incremental value after stimulation. While in adults the most significant level is probably the actual post-stimulation concentration, assessment of 
(Including tests after Tetracosactrin Depot商ind

\begin{tabular}{|c|c|c|c|c|c|c|c|c|c|}
\hline \multirow{2}{*}{$\begin{array}{l}\text { Case } \\
\text { No. }\end{array}$} & \multirow{2}{*}{ Sex } & \multirow{2}{*}{$\begin{array}{l}\text { Age } \\
\text { (yr.) }\end{array}$} & \multirow{2}{*}{$\begin{array}{c}\text { Height } \\
(\mathrm{cm} .) \\
\text { and } \\
\text { Centile }\end{array}$} & \multirow{2}{*}{$\begin{array}{l}\text { Weight } \\
\text { (kg.) } \\
\text { and } \\
\text { Centile }\end{array}$} & \multirow{2}{*}{$\begin{array}{l}\text { Prednis. } \\
\text { Dose } \\
\text { (mg./day) }\end{array}$} & \multirow{2}{*}{$\begin{array}{c}\text { Duration } \\
\text { of } \\
\text { Therapy } \\
\text { (mth.) }\end{array}$} & \multicolumn{3}{|c|}{$\begin{array}{l}\text { Tetracosactrin Test: Plasma } \frac{\bar{\sigma}}{\bar{D}} \\
\text { Cortisol Levels }(\mu \mathrm{g} . / 100 \mathrm{ml} .)\end{array}$} \\
\hline & & & & & & & Base & $30 \mathrm{~min}$. & Increngignt \\
\hline 1 & 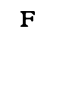 & $6 \cdot 11$ & $\begin{array}{l}122 \cdot 0 \\
(50)\end{array}$ & $\begin{array}{c}27 \cdot 67 \\
(75)\end{array}$ & $\begin{array}{r}10 \\
10 \\
5\end{array}$ & $\begin{array}{l}7 \\
9 \\
2\end{array}$ & $\begin{array}{l}\text { (a) } 2.9 \\
\text { (b) } 1.0 \\
\text { (c) } 5.5\end{array}$ & $\begin{array}{r}2 \cdot 9 \\
1 \cdot 0 \\
14 \cdot 8\end{array}$ & $\begin{array}{l}0.00 \\
0.0 \\
9.30\end{array}$ \\
\hline 2 & $\mathbf{F}$ & $9 \cdot 0$ & $\begin{array}{c}130 \cdot 9 \\
(50)\end{array}$ & $\begin{array}{l}25 \cdot 17 \\
(10)\end{array}$ & $\begin{array}{r}10 \\
10 \\
10 \\
5 \\
5\end{array}$ & $\begin{array}{r}11 \\
14 \\
15 \\
1 \\
2\end{array}$ & $\begin{array}{l}\text { (a) } 2 \cdot 1 \\
\text { (b) } 1 \cdot 0 \\
\text { (c) } 1 \cdot 0 \\
\text { (d) } 4 \cdot 4 \\
\text { (e) } 3 \cdot 5\end{array}$ & $\begin{array}{r}1.0 \\
1.0 \\
1.5 \\
36.5 \\
8.5\end{array}$ & 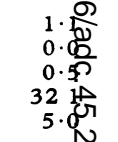 \\
\hline 3 & $\mathbf{M}$ & $5 \cdot 9$ & $\begin{array}{c}110 \cdot 6 \\
(10)\end{array}$ & $\begin{array}{c}21 \cdot 41 \\
(25)\end{array}$ & $\begin{array}{l}10 \\
2 \cdot 5\end{array}$ & $\begin{array}{r}41 \\
2\end{array}$ & $\begin{array}{l}\text { (a) } 1 \cdot 1 \\
\text { (b) } 3 \cdot 7\end{array}$ & $\begin{array}{r}1 \cdot 1 \\
28 \cdot 8\end{array}$ & $\begin{array}{r}0 \cdot \vec{\infty} \\
25 \cdot \dot{\text { nu }}\end{array}$ \\
\hline 4 & F & $8 \cdot 11$ & $\begin{array}{l}128 \cdot 0 \\
(25)\end{array}$ & $\begin{array}{c}26 \cdot 63 \\
(25)\end{array}$ & $\begin{array}{l}10 \\
10 \\
2 \cdot 5\end{array}$ & $\begin{array}{r}39 \\
40 \\
2\end{array}$ & $\begin{array}{l}\text { (a) } 1 \cdot 4 \\
\text { (b) } 2 \cdot 3 \\
\text { (c) } 7 \cdot 9\end{array}$ & $\begin{array}{r}5 \cdot 8 \\
2 \cdot 1 \\
21 \cdot 8\end{array}$ & $\begin{array}{r}4 \cdot 4 \\
0 \cdot 2 \\
13 \cdot 9\end{array}$ \\
\hline 5 & $\mathbf{M}$ & $9 \cdot 0$ & $\begin{array}{c}123 \cdot 1 \\
(3)\end{array}$ & $\begin{array}{c}26 \cdot 44 \\
(25)\end{array}$ & 10 & 8 & (a) $1 \cdot 3$ & $3 \cdot 8$ & 2.5 \\
\hline 6 & $\mathbf{M}$ & $6 \cdot 0$ & $\begin{array}{c}116 \cdot 5 \\
(50)\end{array}$ & $\begin{array}{l}22 \cdot 04 \\
(50)\end{array}$ & 10 & 9 & (a) 1.4 & $1 \cdot 2$ & $0 \cdot \stackrel{0}{2}$ \\
\hline
\end{tabular}

adrenal function in children on this finding may not be valid. For instance, baseline levels are a little lower in children than in adults (J. G. Lines and J. A. Kuzemko, unpublished observations), and consequently the post-corticotrophin rises may not be as high as in adults. Nevertheless, high baseline values may be found if the child is anxious and has good adrenal function. We believe, therefore, that little importance can be attached to the baseline values.

The most useful parameter is to consider the incremental increase in relation to the baseline value. Thus with baseline values in the lower half of the normal range, an incremental increase of more than $10 \mu \mathrm{g} . / 100 \mathrm{ml}$. in the plasma cortisol level following stimulation means adequate adrenal reserve. For baseline values in the upper half of the adult normal range, the incremental increase may be below $10 \mu \mathrm{g} . / 100 \mathrm{ml}$., but in that case the 30-minute value should exceed the upper limit of normal for adults. It is on these criteria that we have classified our results. We cannot support the claim of Kerrebijn et al. (1967) that a single plasma cortisol level less than $6 \mu \mathrm{g}$. $/ 100 \mathrm{ml}$. implies 'hypophyseo-adrenocortical inhibition'.

There appears to be a direct relation between a sudden excessive weight gain in some of these patients and adrenocortical insufficiency as shown by the abnormal tetracosactrin test (Cases 1, 2, 3, and 4 in Table III, and Case 8 in Table II). A consecutive weight increase of about $2 \mathrm{~kg}$. weekly over a minimum period of 3 weeks was associated with an abnormal test. Such children all developed a fine growth of hair at the back of the neck, on arms, and between the scapulae, which persisted even where there had been weight reduction and the tests had returned to normal. We believe the combination of these signs may provide the earliest clinical warning of adrenocortical suppression and are investigating the matter further.

Recently, reports have appeared stressing the increase of death from asthma, especially in children (Smith, 1966; Speizer et al., 1968; Gandevia, 1968). Of the 171 patients of Speizer and his colleagues, 137 died 'unexpectedly and suddenly' and only $39 \%$ were thought to have severe asthma at the time. Moreover, two-thirds received steroids before, but only half during, the final episode. One of our patients (Case 3 in Table III) was originally admitted in coma, thought to be 'diabetic'. It was subsequently established that he had been on prednisolone $10 \mathrm{mg}$. daily for 


\begin{tabular}{|c|c|c|c|}
\hline Remarks & Result & Clinical State & $\begin{array}{l}\text { Bronchial Lability } \\
\text { Index (Jones) }\end{array}$ \\
\hline $\begin{array}{l}\text { Tetracosactrin depot } 1 \mathrm{mg} \text {. daily } \\
\text { for } 3 \text { days, } 40 \text { days before } \\
\text { test (c) }\end{array}$ & $\begin{array}{l}\mathbf{A} \\
\mathbf{A} \\
\mathbf{N}^{\star}\end{array}$ & $\begin{array}{l}\text { Four attacks last } 12 \text { mth. requiring hospital admissions; responded to } \\
\text { bronchodilators; given a course of ACTH gel } 40 \text { units ( } 5 \text { dy.) } \\
4 \mathrm{mth} \text {. before test (b); no response to disodium cromoglycate; } \\
\text { now on } 10 \mathrm{mg} \text {. prednisolone alternate days and occasional } \\
\text { bronchodilator }\end{array}$ & III \\
\hline $\begin{array}{l}\text { Tetracosactrin depot } 1 \mathrm{mg} \text {. daily } \\
\text { for } 3 \text { days, } 15 \text { days before } \\
\text { test (d) }\end{array}$ & $\begin{array}{l}\text { A } \\
\text { A } \\
\text { A } \\
N^{\star} \\
\text { PR }\end{array}$ & $\begin{array}{l}\text { Hospital admission } 6 \text { months ago; had 4-day course of ACTH gel, } \\
40 \text { units, } 3 \text { mth. before test (b); required frequent bronchodilators; } \\
\text { greatly improved on reduced dose of prednisolone and disodium } \\
\text { cromoglycate }\end{array}$ & III \\
\hline $\begin{array}{l}\text { Tetracosactrin depot } 1 \mathrm{mg} \text {. daily } \\
\text { for } 3 \text { days, } 10 \text { days before } \\
\text { test (b) }\end{array}$ & $\begin{array}{l}A \\
N^{\star}\end{array}$ & $\begin{array}{l}\text { Poorly controlled; needs frequent bronchodilators; initial good } \\
\text { response to reduced dose of prednisolone and disodium cromoglycate } \\
\text { (present dose is again } 10 \mathrm{~g} \text {. daily) (type I-hypersensitivity absent) } \ddagger\end{array}$ & $\begin{array}{l}\text { Too young to assess } \\
\text { ( ?III) }\end{array}$ \\
\hline \multirow[t]{3}{*}{$\begin{array}{l}\text { Tetracosactrin depot } 1 \mathrm{mg} \text {. daily } \\
\text { for } 3 \text { days, } 10 \text { days before } \\
\text { test (c) }\end{array}$} & $\begin{array}{l}\text { A } \\
\mathbf{A} \\
\mathbf{N}\end{array}$ & $\begin{array}{l}\text { Sister of Case } 3 \text {; often required antispasmodics in addition to } \\
\text { steroids; now very well on reduced dose of prednisolone and } \\
\text { disodium cromoglycate (type I-hypersensitivity present) } ¥\end{array}$ & III \\
\hline & $\mathbf{A}$ & $\begin{array}{l}\text { Unstable family background; requires occasional antispasmodics and } \\
\text { regular psychiatric support }\end{array}$ & Too young to assess \\
\hline & A & Needs occasional bronchodilator; relapses if steroid dose reduced & Too young to assess \\
\hline
\end{tabular}

2 years, and as he had been well for some weeks his mother had stopped his tablets abruptly 4 days before his admission to hospital. On examination he had a typical Cushingoid appearance and left basal pneumonitis. Recovery was dramatic after $100 \mathrm{mg}$. hydrocortisone intravenously and rehydration. A tetracosactrin test 2 days later gave an abnormal response (plasma cortisol $1 \mu \mathrm{g} . / 100 \mathrm{ml}$. before and after tetracosactrin). Norman (1965) also quotes 2 children with asthma who had signs of adrenal shock associated with upper respiratory tract infections who recovered after hydrocortisone. It is our contention, on reviewing the literature, that many of the deaths attributed to asthma may have been due to adrenal cortical failure secondary to stress, e.g. infection, to which the patient was either not able to respond, or was given too small a dose of steroid (Sampson, Brooke, and Winstone, 1961; Robinson, Mattingly, and Cope, 1962; El-Shaboury, 1966; Gregg and Batten, 1969). Moreover, Dwyer, Lazarus, and Hickie (1967) pointed out that large doses of cortisol were necessary to treat acute episodes in patients on long-term steroids, and satisfactory clinical responses were obtained only when the plasma cortisol level was raised to at least $100 \mu \mathrm{g} . / 100 \mathrm{ml}$.
We contend that if these facts are appreciated, the deaths from asthma will decrease. We suggest that before steroids are reduced a tetracosactrin test be carried out and that the test should be done at regular intervals in all children receiving more than $2.5 \mathrm{mg}$. prednisolone daily.

We fully agree with the conclusions of a recent Leader (Lancet, 1968) that: 'The main need seems to be for better assessment and care of patients with asthma' and support the view that units should be set up to deal with the asthmatic child, as is the case at present with other chronic disorders, e.g. diabetes mellitus. The extent of adrenocortical suppression by exogenous steroids can be readily determined by the use of this test and the existence of easily accessible units with the appropriate laboratory facilities might contribute much to reducing mortality from asthma in children.

We would like to thank Dr. B. W. Powell for allowing us to include three patients under his care.

\section{REFERENCES}

Alleyne, G. A. O., and Young, V. H. (1966). Test of adrenocortical reserve in children. (Correspondence.) Lancet, $2,503$.

Coombs, R. R. A., and Gell, P. G. H. (1968). Classification of allergic reactions responsible for clinical hypersensitivity and disease. In Clinical Aspects of Immunology. 2nd ed., p. 575. 
Ed. by P. G. H. Gell and R. R. A. Coombs. Blackwell, Oxford.

Dwyer, J., Lazarus, L., and Hickie, J. B. (1967). A study of cortisol metabolism in patients with chronic asthma. Australian Annals of Medicine, 16, 297.

El-Shaboury, A. H. (1966). Adrenal failure complicating status asthmaticus in steroid treated patients. British Medical Fournal, 2, 1478.

Gandevia, B. (1968). The changing pattern of mortality from asthma in Australia. 2. Mortality and modern therapy. Medical Fournal of Australia, 1, 884.

Gregg, I., and Batten, J. (1969). Sudden death in a young asthmatic. British Medical fournal, $2,29$.

Greig, W. R., Browning, M. C. K., Boyle, J. A., and Maxwell, J. D. (1966). Effect of synthetic polypeptide $\beta^{1-24}$ (Synacthen) on adrenocortical function. Fournal of Endocrinology, 34, 411.

Jones, R. S. (1966). Assessment of respiratory function in the asthmatic child. British Medical fournal, 2, 972.

Kerrebijn, K. F., de Kroon, J. P. M., and Harders, C. L. (1967). Corticosteroid therapy in children with asthma. Hypophyseoadrenocortical inhibition. Archives of Disease in Childhood, 42, 532 .

Lancet (1968). Leading article. Death from asthma, 1, 1412.

Landon, J., Wynn, V., and James, V. H. T. (1963). The adrenocortical response to insulin induced hypoglycaemia. fournal of Endocrinology, 27, 183.

McGill, P. E., Greig, W. R., Browning, M. C. K, and Boyle, J. A. (1967). Plasma cortisol response to Synacthen $\left(\beta^{1-24} \mathrm{Ciba}\right)$ at different times of the day in patients with rheumatic diseases. Annals of the Rheumatic Diseases, 26, 123.

Mattingly, D. (1962). A simple fluorimetric method for the estimation of free 11-hydroxycorticoids in human plasma. fournal of Clinical Pathology, 15, 374.

Melby, J. C. (1959). Assessment of adrenocorticotrophic activity with bacterial pyrogen in hypopituitary states (abstr.). fournal of Clinical Investigation, 38, 1025.

Mills, J. N. (1966). Human circadian rhythms. Physiological Reviezws, 46, 128.

de Moor, P., Steeno, O., Raskin, M., and Hendrikx, A. (1960). Fluorimetric determination of free plasma 11-hydroxycorti- costeroids in man. Acta Endocrinologica (Copenhagen), 33, 297.

Norman, A. P. (1965). Steroid treatment in asthma. In Recent $\Rightarrow$ Advances in Paediatrics, 3rd ed., p. 301. Ed. by D. Gairdner. Churchill, London.

Pearson, R. S. B. (1959). Steroid therapy in asthma. Postgraduate Medical fournal, 35, 463.

Rao, Kamala S. Jaya, Srikantia, S. G., and Gopalan, C. (1968) $\frac{\overline{\bar{v}}}{\mathrm{~s}}$ Plasma cortisol levels in protein-calorie malnutrition. Archives of Disease in Childhood, 43, 365.

Robinson, B. H. B., Mattingly, D., and Cope, C. L. (1962). Adrenal function after prolonged corticosteroid therapy.es British Medical fournal, 1, 1579.

Sampson, D. A., Brooke, B. N., and Winstone, N. E. (1961) $\overrightarrow{0}$ Biochemical confirmation of collapse due to adrenal failureLancet, 1, 1377.

Shuster, S., and Williams, I. A. (1961). Pituitary and adrenab function during administration of small doses of corticosteroids Lancet, 2, 674.

Smith, J. M. (1966). Death from asthma (letter to Editor)? Lancet, 1, 1042.

Speizer, F. E., Doll, R., Heaf, P., and Strang, L. B. (1968). Investi or gation into use of drugs preceding death from asthma. British Medical fournal, $1,339$.

Tanner, J. M., Whitehouse, R. H., and Takaishi, M. (1966)त Standards from birth to maturity for height, weight, heigh velocity, and weight velocity. British children, 1965. Archives of Disease in Childhood, 41, 454 and 613.

Treadwell, B. L. J., Savage, O., Sever, E. D., and Copeman, W. S. C... (1963). Pituitary-adrenal function during corticosteroid therapy Lancet, 1, 355.

Wilson, L. A. (1951). Protein shock from intravenous ACTH Lancet, $2,478$.

Wood, J. B., Frankland, A. W., James, V. H. T., and Landon, J $\overrightarrow{6}$ (1965). A rapid test of adrenocortical function. Lancet, 10 243.

Correspondence to Dr. J. A. Kuzemko, Peterborough District Hospital, Midland Road, Peterborough. 